UDC 616.98:579.842.23

DOI: $10.21668 /$ health.risk/2020.4.14.eng

Research article

\title{
IMMUNOLOGIC MONITORING OVER PEOPLE VACCINATED AGAINST PLAGUE IN CASPIAN SAND NATURAL FOCUS IN ORDER TO ASSESS AND MANAGE HEALTH RISKS
}

\section{S.A. Bugorkova, S.N. Klyueva, O.M. Kudryavtseva, V.P. Toporkov, T.N. Shchukovskaya, A.L. Kravtsov, N.I. Mikshis, M.A. Tarasov, S.A. Shcherbakova, V.V. Kutyrev}

«Microbe» Russian Scientific Research Anti-Plague Institute, 46 Universitetskaya Str., Saratov, 410005, Russian Federation

To provide better opportunities for managing both risks caused by vaccination and risks of epidemiological complications, immunologic monitoring over people vaccinated with live dried plague vaccine (LPV) due to epidemiologic indications was performed.

Our research goal was to assess whether immunologic monitoring over people vaccinated against plague yielded informative results; it was done to substantiate activities aimed at improving procedures for LPV application. Immunologic monitoring was performed from 2016 to 2019 in the Caspian sand natural plague focus according to conventional procedures for assessing humoral and cellular components in immunity.

We determined immunologic parameters in 217 volunteers vaccinated with LPV and 130 healthy donors (the reference group) prior to and 1 and 12 months after vaccination. We suggested a methodical approach based on aggregated analysis of the summated immune response predictors chosen for estimation in volunteers vaccinated with LPV and giving score values to them; it allows revealing people who react to plague microbe antigens predominantly as per cellular, humoral, or mixed type.

Immunologic monitoring results proved that it was safe to apply LPV; they allowed characterizing trends occurring in immunological restructuring in vaccinated volunteers, determining limits of fluctuation in individual parameters of an immune response to the vaccine, and revealing people with both normal and changed (reduced or increased) immunologic reactivity to $L P V$. If monitoring data are taken into account, it provides an opportunity to predict vaccination results as per epidemiological parameters, to reveal groups with normal, high, or low immune reactivity to plague microbe antigens in order to determine people in them who need an individual approach when it comes down to anti-plague vaccination.

Key words: plague prevention, live plague vaccine (LPV), immunologic monitoring, cellular and humoral immunity, plague microbe antigens, immune reactivity, epidemiologic complications, health risk management.

(C) Bugorkova S.A., Klyueva S.N., Kudryavtseva O.M., Toporkov V.P., Shchukovskaya T.N., Kravtsov A.L., Mikshis N.I., Tarasov M.A., Shcherbakova S.A., Kutyrev V.V., 2020

Svetlana A. Bugorkova - Doctor of Medical Sciences, Chief researcher at the Immunology Department (e-mail: rusrapi@ microbe.ru; tel.: +7 (927) 621-24-10; ORCID: https://orcid.org/0000-0001-7548-4845).

Svetlana N. Klyueva - Candidate of Biological Sciences, Researcher at the Immunology Department (e-mail: klyueva.cvetlana@mail.ru; tel.: +7 (452) 26-21-31; ORCID: https://orcid.org/0000-0001-5550-6063).

Ol'ga M. Kudryavtseva - Candidate of Biological Sciences, Senior researcher at the Immunology Department (e-mail: rusrapi@microbe.ru; tel.: +7 (905) 369-71-99, +7 (452) 26-21-31; ORCID: https://orcid.org/0000-0002-9894-3394).

Vladimir P. Toporkov - Doctor of Medical Sciences, Professor, Chief researcher at the Laboratory for Epidemiologic Analysis and Prediction (e-mail: rusrapi@microbe.ru; tel.: +7 (8452) 73-46-48; ORCID: https://orcid.org/0000-0001-9512-7415).

Tat'yana N. Shchukovskaya - Doctor of Medical Sciences, Professor, Chief researcher at the Immunology Department (e-mail: rusrapi@microbe.ru; tel.: +7 (452) 26-21-31; ORCID: https://orcid.org/0000-0001-8995-0894).

Aleksandr L. Kravtsov - Doctor of Biological Sciences, Leading researcher at the Immunology Department (e-mail: rusrapi@microbe.ru; tel.: +7 (452) 26-21-31; ORCID: https://orcid.org/0000-0002-9016-6578).

Natal'ya I. Mikshis - Doctor of Medical Sciences, Chief researcher at the Immunology Department (ORCID: https://orcid.org/0000-0001-8969-785X).

Mikhail A. Tarasov - Doctor of Biological Science, Senior researcher at the laboratory for epizootologic monitoring (e-mail: rusrapi@microbe.ru; tel.: +7 (452) 26-21-31; ORCID: https://orcid.org/0000-0003-1980-6605).

Svetlana A. Shcherbakova - Doctor of Biological Sciences, Deputy Director for Science and Experimental Work (e-mail: rusrapi@microbe.ru; tel.: +7 (8452) 21-54-43; ORCID:https://orcid.org/0000-0003-1143-4069).

Vladimir V. Kutyrev - RAS Academician, Doctor of Medical Sciences, Professor, Director (e-mail: rusrapi@microbe.ru; tel.: +7 (452) 26-21-31; ORCID: https://orcid.org/0000-0003-3788-3452). 
Fleas and rodents that are common for the Caspian natural sand plague focus often get infected with plague and such epidemics are wide-scale and appear with certain periodicity [1]. As a rule, in the past when an epizootic situation deteriorated drastically in the Caspian sand natural plague focus, the process was accompanied with epidemiological complications [2]. In 2014 it was only timely reacting that allowed preserving epidemiologically favorable situation when there was another wave of epizooties on the territory; this reacting involved timely activities aimed at specific and non-specific plague prevention [2, 3]. Breaking a chain of epidemic complications occurring in the Mountain Altai natural plague focus in 2014-2016 is a good example of successfully implemented activities aimed at specific plague prevention $[4,5]$.

Anti-plague vaccination is a component in the set of activities aimed at providing prevention from this infection in its natural foci. And a scope of specific anti-plague prevention can be different in each specific natural focus. It depends on intensity of epizootic activity in a natural focus, epidemic peculiarities, overall population density in a focus, types of economic activities performed on an enzootic territory as they determine how frequently people can enter a contact with infected objects, natural and climatic conditions, and socioeconomic development of a region that determines availability of laboratory and medical support.

In Russia specific plague prevention involves using live dried plague vaccine (LPV) which is a dried live culture of a vaccine strain belonging to a plague microbe

Yersinia pestis EV developed by the Scientific Research Institute for Epidemiology and Hygiene and produced by Rospotrebnadzor's Stavropol Scientific Research Antiplague Institute. A single cutaneous vaccination with LPV results in high-level immunity occurrence that persists up to a year and it means that people living on risk territories are to be revaccinated annually in case there is epizootic activity among plague agents.

Specific plague prevention strategy is determined by the National Calendar for Preventive Vaccinations as per epidemic indications ${ }^{1}$ and involves vaccinating people who live on a territory that is enzootic as per plague and personnel working at specialized institutions who deal with live plague agent cultures. In case there are complications in an epizootic situation (plague epizooty among rodents) and/or epidemic one (farm animals or people get infected or there is a risk that plague will be transferred onto a territory), tactic anti-plague activities aimed at specific prevention among people who temporarily or permanently live in a natural plague focus involve vaccination of all people on a limited territory, starting from 2-year old children; or only selected occupational groups who run the highest risks are to be vaccinated (cattle-breeders, agronomists, farmers, geologists, hunters, or suppliers). To provide vaccination for all the people living a region can be rather costly, and, bearing in mind negative attitudes most people usually have towards vaccinations, it implies a necessity to implement wide-scale sanitaryeducational activities. Given that, a probable solution could be providing people with convincing motivation for vaccination necessity confirmed with explicit data on assessing immune reactions to plague microbe in each vaccinated person.

Providing vaccination with maximum possible excess of benefit (efficiency) over risks is a basic goal in risk management in vaccine studies $[6,7]$.

Immunologic monitoring over people who got vaccinated with LPV as per epidemic indications provides better opportunities for managing risks caused by vaccination itself and risks related to possible complications of an epidemiologic situation. When vaccination is performed without taking into account hetero-

\footnotetext{
${ }^{1}$ On Approval of the National Calendar for Preventive Vaccinations and Vaccinations required as per epidemiologic indications: The Order by the RF Public Healthcare Ministry No. 125n dated March 21, 2014. KODEKS: an electronic fund for legal and reference documentation. Available at: http://docs.cntd.ru/document/499086215 (10.02.2020) (in Russian).
} 
geneity of vaccinated population groups (immunization scheme and doze are the same), it doesn't allow applying a methodology for managing potential risks related to vaccination prevention; therefore, an epidemic process is not managed efficiently [8]. Hence, a key moment in optimizing specific plague prevention is to create a methodical approach to a complex assessment of results obtained via immunologic, epizootologic, and epidemiologic monitoring in a natural plague focus; such an approach should be aimed at determining a risk territory and a risk period as well as at substantiating targets and scopes of prevention activities regarding risk groups among population.

Our research goal was to assess information value of results obtained via immunologic monitoring over people who got vaccinated against plague in order to substantiate implementation of activities aimed at improving tactics in LPV application.

Data and methods. We performed monitoring over 347 volunteers in the Caspian sand natural plague focus in 2016-2019. Our participants were people living in Chernozemelskiy district, Kalmyk Republic, and experts employed at 2 anti-plague institutions 9 in Elista and Astrakhan). The research was performed in accordance with the research program and procedure approved by the Biological Ethical Committee of V.I. Razumovskiy's Saratov State Medical University. All the volunteers gave their written informed consent to take part in the research.

All the volunteers (217 people) got cutaneous vaccination with LPV (LSR-005759/08) produced by Rospotrebnadzor's Stavropol Scientific Research Anti-plague Institute (Russia).
We applied the following preparation series in our research: $1-15 ; 2-16 ; 3-15 ; 5-14$.

We assessed immunologic efficiency and safety of LPV applied for vaccinating different research groups prior to vaccination as well as 1 and 12 months after it. Our research groups included Group 1 (volunteers who got vaccinated for the $1^{\text {st }}$ time); Group 2 (people who got vaccinated for the $2^{\text {nd }}$ and the $3^{\text {rd }}$ time); Group 3 (experts from antiplague institutions located in the Caspian sand natural plague focus who were vaccinated multiple times); and the Reference group (130 healthy donors who permanently resided in Kalmyk Republic). Overall characteristics of people who participated in the research are given in Table 1.

To characterize risks that adverse effects related to vaccination might occur among volunteers, we analyzed primary medical documents (Form No. 025/u) and questionnaires that were offered to volunteers during their second visit (1 month after vaccination). LPV safety was assessed as per results obtained via analyzing indirect immunologic tests aimed at determining the following:

- contents of circulating immune complexes (CIC) in blood serum of vaccinated people via PEG-precipitation;

- E immunoglobulin (IgE) concentration according to the instructions provided with a reagents set for ELISA determination of total E immunoglobulin in blood serum, total $\operatorname{IgE}$, IFA-BEST test as per TU (technical conditions) 9398-048-23548172-2006;

- CD95+ (APO-1) apoptosis marker, Fas ligand cellular receptor, via flow cytometry according to the instructions provided by a manufacturer (Beckman Coulter Inc., the USA) [9].

Table 1

Research participants: overall characteristics

\begin{tabular}{|c|c|c|c|c|c|}
\hline & arameter & $\begin{array}{l}\text { Group 1 } \\
(n=20)\end{array}$ & $\begin{array}{l}\text { Group 2 } \\
(n=94)\end{array}$ & $\begin{array}{l}\text { Group 3 } \\
(n=103)\end{array}$ & $\begin{array}{l}\text { Reference group } \\
\quad(n=130)\end{array}$ \\
\hline \multicolumn{2}{|c|}{$\begin{array}{l}\text { Age (years) } \\
\text { Me (Q25\%-Q75\%) }\end{array}$} & $38(30-44)$ & $39(32-48)$ & $43(38-53.5)$ & $33(31-36)$ \\
\hline \multirow{2}{*}{$\begin{array}{l}\text { Sex } \\
(\mathrm{Abs} . / \%)\end{array}$} & Males & $11(55 \%)$ & $32(34 \%)$ & $54(52 \%)$ & $44(33.8 \%)$ \\
\hline & Females & $9(45 \%)$ & $62(66 \%)$ & $49(48 \%)$ & $86(66.2 \%)$ \\
\hline
\end{tabular}


Parameters of LPV safety, Me (Q25\%-Q75\%)

\begin{tabular}{|c|c|c|c|c|c|c|}
\hline \multirow[b]{2}{*}{$\begin{array}{l}\text { Monitoring } \\
\text { period }\end{array}$} & \multicolumn{4}{|c|}{ Group } & \multirow[b]{2}{*}{$P<0.05^{*}$} & \multirow[b]{2}{*}{$P<0.05^{* *}$} \\
\hline & $\begin{array}{c}1 \\
(n=20)\end{array}$ & $\begin{array}{c}2 \\
(n=62)\end{array}$ & $\begin{array}{c}3 \\
(n=59)\end{array}$ & $\begin{array}{c}\text { reference } \\
(n=30)\end{array}$ & & \\
\hline \multicolumn{7}{|c|}{$\operatorname{IgE}$ (conditionally healthy donor: $20-100 \mathrm{IU} / \mathrm{ml}$ ) } \\
\hline Prior to vaccination & $\begin{array}{c}5.2 \\
(1.4-65.4)\end{array}$ & $\begin{array}{c}35.6 \\
(16.7-123.1) \\
\end{array}$ & $\begin{array}{c}18.3 \\
(3.8-75.8) \\
\end{array}$ & \multirow{2}{*}{$\begin{array}{c}14.7 \\
(5.6-32.9)\end{array}$} & $1 ; 2$ & $1 ; 2$ \\
\hline 1 month after & $\begin{array}{c}11.0 \\
(6.1-27.1)\end{array}$ & $\begin{array}{c}49.0 \\
(14.8-143.7) \\
\end{array}$ & $\begin{array}{c}12.8 \\
(2.9-58.4)\end{array}$ & & 2 & $\begin{array}{l}1 ; 2 \\
2 ; 3\end{array}$ \\
\hline \multicolumn{7}{|c|}{ CD95 (conditionally healthy donor: $0-7 \%$ ) } \\
\hline Prior to vaccination & $\begin{array}{c}3.6 \\
(3.05-3.85)\end{array}$ & $\begin{array}{c}3.2 \\
(2.95-3.35)\end{array}$ & $\begin{array}{c}6.0 \\
(4.98-6.4)\end{array}$ & \multirow{2}{*}{$\begin{array}{c}4.4 \\
(3.99-4.55)\end{array}$} & 3 & $\begin{array}{l}1 ; 3 \\
2 ; 3\end{array}$ \\
\hline 1 month after & $\begin{array}{c}3.7 \\
(2.95-3.75)\end{array}$ & $\begin{array}{c}4.0 \\
(3.89-4.32)\end{array}$ & $\begin{array}{c}6.0 \\
(5.48-6.21)\end{array}$ & & 3 & $1 ; 3$ \\
\hline \multicolumn{7}{|c|}{ CIC (conditionally healthy donor: $90-95 \%$ ) } \\
\hline Prior to vaccination & $\begin{array}{c}71.2 \\
(68.4 ; 93.9)\end{array}$ & $\begin{array}{c}84.5 \\
(42.8 ; 92.1)\end{array}$ & $\begin{array}{c}90.4 \\
(65.4 ; 87.4)\end{array}$ & \multirow{2}{*}{$\begin{array}{c}76.9 \\
(54.2 ; 82.1)\end{array}$} & - & - \\
\hline 1 month after & $\begin{array}{c}81.2 \\
(45.8 ; 91.7) \\
\end{array}$ & $\begin{array}{c}86.9 \\
(56.4 ; 90.5)\end{array}$ & $\begin{array}{c}89.7 \\
(49.8 ; 97.2)\end{array}$ & & - & - \\
\hline \multicolumn{7}{|c|}{ IRI } \\
\hline Prior to vaccination & $\begin{array}{c}1.7 \\
(1.4-2.2)\end{array}$ & $\begin{array}{c}1.6 \\
(1.2-1.9)\end{array}$ & $\begin{array}{c}1.4 \\
(1.2-1.9)\end{array}$ & \multirow{2}{*}{$\begin{array}{c}1.7 \\
(1.4-2.2)\end{array}$} & - & - \\
\hline 1 month after & $\begin{array}{c}2.7 \\
(2.3-3.2)^{* * *} \\
\end{array}$ & $\begin{array}{c}1.2 \\
(1.0-1.5) \\
\end{array}$ & $\begin{array}{c}1.6 \\
(1.3-2.2) \\
\end{array}$ & & $1 ; 2$ & $\begin{array}{l}1 ; 2 \\
1 ; 3\end{array}$ \\
\hline
\end{tabular}

Note:

* means validity of discrepancy against reference group;

** means validity of discrepancy between groups $1 ; 2 ; 3$;

*** means validity of discrepancy against «prior to vaccination» period.

These parameters were estimated prior to vaccination and 1 month after it. We assessed changes in immune regulatory index (IRI) that was determined as a ratio of a number of cells with CD4 phenotype to a number of cells with CD8 phenotype (CD4/CD8) prior to vaccination with LPV and 12 months after it.

We performed ELISA tests with ELISA commercial sets (Vector-Best, Cytokine, Russia) and "ELISA-AT-F1 YERSINIA PESTIS» test system («Microbe», Rospotrebnadzor's Russian Scientific Research Anti-plague Institute) and assessed immunologic efficiency of vaccination with LPV in accordance with manufacturers' instructions as per changes in parameters of Th-1 (IFN- $\gamma$, TNF- $\alpha$ ) and Th- 2 (IL4) associated cytokines production induced by Concanavalin A (Sigma), and in the level of specific antibodies to capsule plague microbe antigen (F1). We analyzed parameters obtained prior to vaccination as well as 1 and 12 months after it.

Research results were processed with non-parametric statistic procedures using STATISTICA $10 \mathrm{RU}$ and MS Office Excel 2007 software packages. Mathematic analysis procedures applied to analyzed results obtained via immunologic monitoring over the volunteers involved assessing authenticity of all obtained laboratory parameters via calculating inter-group associations with MannWhitney U-test; to make comparisons within a group, we applied Wilcoxon's T-test [10]. Discrepancies were considered to be significant at $p<0.05$. To analyze correlations between basic parameters of cellular and humoral immunity and to determine significance of their key parameters, we performed multidimensional trial analysis with StatSoftStatistica.ru software package. We determined 
parameters that predicted immunologic restructuring efficiency of anti-plague vaccination [11].

Results and discussion. When analyzing records on prevention vaccination of volunteers who got vaccinated with LPV and questionnaires, we didn't detect any cases when somebody applied for medical aid due to overall or local reactions to vaccination. There were no complaints about any changes in health, and questionnaires allowed revealing that skin reddening on a spot where vaccine was introduced into a body developed in only $5-7 \%$ volunteers.

Table 2 contains the results obtained via assessing indirect immunologic parameters of LPV safety.

Overall analysis of all these parameters didn't reveal any significant CIC accumulation and statistically authentic increase in a share of cells that had CD95+, early apoptosis activation marker. Values of all these parameters were within ranges fixed for conditionally healthy donors and didn't differ authentically from data obtained for the reference group that was made up of volunteers who hadn't previously been vaccinated with LPV.

A detected increase in IgE contents in blood of some volunteers was still within reference values for conditionally healthy donors and didn't correlate with increased IL-4 contents. Increased $\mathrm{IgE}$ contents in people who were going to get vaccinated or just after vaccination were also revealed in similar research performed in the Mountain Altai natural plague focus and they were also within reference ranges fixed for conditionally healthy donors [12].

There was evidence that LPV was quite safe; namely, absence of people with a decrease in IRI 12 months after vaccination against the initial level of this parameter in volunteers prior to vaccination.

Immunologic monitoring also involves characterizing immunologic restricting in vaccinated volunteers during 12-month monitoring period; we determined ranges of fluctuations in individual immune responses to LPV depending on sex, age, number of previous vaccinations and HLA haplotype of vaccinated people [13].
We characterized induced production of Th1 (INF- $\gamma$, TNF- $\alpha$ ) and Th2 (IL-4) associated cytokines in dynamics and established that there was significant Th1-cells activation aimed at producing cytokines associated with them during the whole monitoring period [13]. As an inductor, Concavalin A, a standard commercial T-cell mitogen and TLR2 ligand, was applied [14]. High IFN- $\gamma$ and TNF- $\alpha$ concentration was detected in all volunteers who got vaccinated with LPV and it was authentically $(p<0.05)$ higher than the same parameter in people from the reference group. In most cases the trend persisted, especially for IFN- $\gamma$, up to the $12^{\text {th }}$ month of monitoring. We estimated stimulation index (SI) that was determined as a ratio of induced cytokine production to spontaneous one for IFN- $\gamma$ and TNF- $\alpha$ and revealed an ascending trend for the parameter as a response to vaccination with LPV. It is interesting to note that SI value in volunteers from Group 2 didn't just go down but grew significantly 12 months after vaccination. There was a descending trend in IL-4 concentration up to the $12^{\text {th }}$ month of monitoring but there was a certain increase in IL-4 concentration among people from Group 31 month after vaccination. At the same time, SI for IL-4 grew in all groups but this growth persisted up to the $12^{\text {th }}$ months in Group 3 only. It should be noted that similar trends in IFN- $\gamma$, TNF- $\alpha$ and IL-4 responses were registered in volunteers who got vaccinated for the $1^{\text {st }}$ time in the Mountain Altai and Tuva Mountain natural plague foci $[12,15]$.

We assessed specific antibody response regarding capsule plague microbe antigen (F1); the assessment revealed gradual growth in specific antibodies titer in all vaccinated volunteers. A number of people with specific antibodies titer at a diagnostic level (1:80) in Group 1 reached $60 \%$ only by the $12^{\text {th }}$ month after vaccination with LPV, but as for Groups 2 and 3, specific antibodies at a diagnostic titer level and higher were registered in $57.5 \%$ and $78 \%$ cases accordingly already 1 month after vaccination. We preformed statistical analysis ( $\chi^{2}$ or Pearson's test) of specific antibodies to plague microbe and revealed that a number of previous vaccinations exerted its influence on 
detected antibodies level $\left(\chi_{1,2}^{2}=16.79 ; p<0.05\right.$ and $\chi_{1,3}^{2}=45.97 ; p<0.001$ and $\chi_{2,3}^{2}=10.92$; $p<0.05)$, but these discrepancies between Groups 1 and 2 leveled off $\left(\chi_{1,2}^{2}=5.25 ; p>0.05\right)$ 12 months after vaccinations and remained only against Group $3\left(\chi_{1,3}^{2}=14.5 ; p<0.05\right.$ and $\chi_{2,3}^{2}=7.04 ; p<0.056$ months after; $\chi_{1,3}^{2}=9.54$; $p<0.05$ and $\chi_{2,3}^{2}=3.13 ; p>0.0512$ months after). However, a share of people with positive seroconversion didn't reach $100 \%$ among those vaccinated against plague and as per literature data specific antibodies occurrence doesn't always correlate with a body being protected from plague infection [16]. A leading role in anti-plague immunity formation belongs to cellular factor; therefore, serologic assessment of immunologic efficiency doesn't properly describe actual immune-biological restricting in a body as a response to LPV introduction [17]. The most adequate way to describe it is to assess cytokines in cultures of whole blood cells in vivo as it allows obtaining data in functional activity of different immunecompetent cells and ratios between activation of T-helpers, Type 1 and 2 [18].

Experiments performed on bubonic and pneumonic plague models allowed proving that high titers of antibodies to $Y$. pestis antigens combined with low activity of IFN- $\gamma$, TNF- $\alpha$, IL-17 cytokines synthesis didn't protect biological model animals (inbred mice, anthropoid and non-anthropoid apes) from death due to plague infection [19].

We assessed cellular immunity activation using results obtained via analyzing data given in Table 3.

Table 3

Characteristics of induced cytokines production in volunteers vaccinated with LPV, Me (Q25\%-Q75\%)

\begin{tabular}{|c|c|c|c|c|c|c|}
\hline \multirow{2}{*}{$\begin{array}{l}\text { Monitoring } \\
\text { period }\end{array}$} & \multicolumn{4}{|c|}{ Group } & \multirow[b]{2}{*}{$P<0.05^{*}$} & \multirow[b]{2}{*}{$P<0.05^{* *}$} \\
\hline & $\begin{array}{c}1 \\
(n=20)\end{array}$ & $\begin{array}{c}2 \\
(n=62) \\
\end{array}$ & $\begin{array}{c}3 \\
(n=59)\end{array}$ & $\begin{array}{c}\begin{array}{c}\text { reference } \\
(n=30)\end{array} \\
\end{array}$ & & \\
\hline \multicolumn{7}{|c|}{ IFN- $\gamma$ (conditionally healthy donor: $165-7,450 \mathrm{pg} / \mathrm{ml})$} \\
\hline $\begin{array}{l}\text { Prior to vacci- } \\
\text { nation }\end{array}$ & $\begin{array}{c}85.5 \\
(12.8 ; 214.2)\end{array}$ & $\begin{array}{c}7.4 \\
(3.3 ; 11.8) \\
\end{array}$ & $\begin{array}{c}121.7 \\
(58.1 ; 169.5) \\
\end{array}$ & \multirow{3}{*}{$\begin{array}{c}112.0 \\
(101.4 \\
122.2)\end{array}$} & 2 & $\begin{array}{l}1 ; 2 \\
2 ; 3\end{array}$ \\
\hline 1 month after & $\begin{array}{c}159.2 \\
(14.6 ; 457.6)\end{array}$ & $\begin{array}{c}10.4 \\
(4.5 ; 17.1) \\
\end{array}$ & $\begin{array}{c}313.6 \\
(143.0 ; 467.3)^{* * *}\end{array}$ & & $2 ; 3$ & $\begin{array}{l}1 ; 2 \\
2 ; 3\end{array}$ \\
\hline $\begin{array}{l}12 \text { months } \\
\text { after. }\end{array}$ & $\begin{array}{c}245.9 \\
(194.6 ; 281.7)^{* * *}\end{array}$ & $\begin{array}{c}235.7 \\
(135.6 ; 325.7)^{* * *}\end{array}$ & $\begin{array}{c}250.0 \\
(137.2 ; 329.5)^{* * *}\end{array}$ & & $1 ; 2 ; 3$ & - \\
\hline \multicolumn{7}{|c|}{ TNF- $\alpha$ (conditionally healthy donor: $391-2,700 \mathrm{pg} / \mathrm{ml})$} \\
\hline $\begin{array}{l}\text { Prior to vacci- } \\
\text { nation }\end{array}$ & $\begin{array}{c}26.5 \\
(21.7 ; 41.7) \\
\end{array}$ & $\begin{array}{c}18.9 \\
(14.6 ; 22.0) \\
\end{array}$ & $\begin{array}{c}29.0 \\
(26.6 ; 39.4) \\
\end{array}$ & \multirow{3}{*}{$\begin{array}{c}63.7 \\
(60.8 ; 104.1)\end{array}$} & $1 ; 2 ; 3$ & - \\
\hline 1 month after & $\begin{array}{c}67.3 \\
(5.7 ; 102.2)\end{array}$ & $\begin{array}{c}3.1 \\
(1.8 ; 5.0)\end{array}$ & $\begin{array}{c}69.5 \\
(35.4 ; 147.4)\end{array}$ & & 2 & $\begin{array}{l}1 ; 2 \\
2 ; 3\end{array}$ \\
\hline $\begin{array}{l}12 \text { months } \\
\text { after. }\end{array}$ & $\begin{array}{c}32.9 \\
(20.4 ; 49.7) \\
\end{array}$ & $\begin{array}{c}64.9 \\
(33.5 ; 109.9) \\
\end{array}$ & \begin{tabular}{|c|}
33.5 \\
$(19.5 ; 58.9)$ \\
\end{tabular} & & $1 ; 3$ & $\begin{array}{l}1 ; 2 \\
2 ; 3 \\
\end{array}$ \\
\hline \multicolumn{7}{|c|}{ IL-4 (conditionally healthy donor: $0-24 \mathrm{pg} / \mathrm{ml}$ ) } \\
\hline $\begin{array}{l}\text { Prior to vacci- } \\
\text { nation }\end{array}$ & $\begin{array}{c}2.1 \\
(1.3 ; 3.8) \\
\end{array}$ & \begin{tabular}{|c|}
6.0 \\
$(4.4 ; 8.1)$ \\
\end{tabular} & \begin{tabular}{|c|}
3.6 \\
$(0.6 ; 2.7)$ \\
\end{tabular} & \multirow{3}{*}{$\begin{array}{c}1.8 \\
(1.2 ; 2.2)\end{array}$} & 2 & $1 ; 2$ \\
\hline 1 month after & $\begin{array}{c}3.0 \\
(2.3 ; 6.8) \\
\end{array}$ & $\begin{array}{c}2.9 \\
(0.9 ; 8.8) \\
\end{array}$ & $\begin{array}{c}5.3 \\
(0.5 ; 4.3)\end{array}$ & & $1 ; 2 ; 3$ & - \\
\hline $\begin{array}{l}12 \text { months } \\
\text { after. }\end{array}$ & $\begin{array}{c}0.4 \\
(0.2 ; 0.8) \\
\end{array}$ & $\begin{array}{c}0.8 \\
(0.4 ; 1.4)^{* * *}\end{array}$ & $\begin{array}{c}0.6 \\
(0.3 ; 1.3)^{* * *}\end{array}$ & & 1 & - \\
\hline
\end{tabular}

Note:

* means validity of discrepancy against reference group;

** means validity of discrepancy between groups $1 ; 2 ; 3$;

$* * *$ means validity of discrepancy against «prior to vaccination» period. 
When assessing efficiency of anti-plague vaccination, there is an issue that remains unresolved, namely, what instruments are to be used for monitoring over population immunity and it is still unclear what level of specific antibodies can provide proper protection from the disease. Therefore, when it is necessary to determine scopes of specific plague prevention for the next epidemiologic season, we suggest assessing LPV immunologic efficiency as per data obtained during the previous season but taking into account predicted and current epizootic situation in a natural focus and/or risks that epidemiologic complications might occur. Further planning of activities on specific plague prevention in a specific natural focus should be based on these data taking into account individual immune reactivity of people who are going to get vaccinated.

This stage in our research was performed with the use of a created database entitled « $\mathrm{Pa}$ rameters of immunologic monitoring over people vaccinated against plague» (RU 2019620831).

We have developed a methodical approach according to which a reaction to vaccination with LPV in a volunteer should be given with scores (from 1 to 4); 1 score means an immune response to vaccination has not occurred; 2 scores mean that predominantly humoral response has occurred and there are specific antibodies to capsule plague microbe antigen F1 (1:80 and higher for those vaccinated for the $1^{\text {st }}$ time, and 1:160 and higher for revaccinated people) and there are no reaction from cellular response predictors (induced production of Th1-associated cytokines is at the same level as prior to vaccination/revaccination); 3 scores mean that there is a mixed response when there is a growth in specific antibodies to F1 titer (higher than a diagnostic level of an applied test-system) and a positive trend in cellular immunity activation (level of induced Th1-associated cytokines production is not less than 2 times higher 12 months after vaccination than prior to it); 4 scores mean that immune response is predominantly cellular (marker cytokines content is 5 or more times higher 12 months after vaccination/revaccination than prior to it regard- less of specific antibodies to F1 occurrence). It is possible to determine predominant type of immune response to LPV for each person who is going to get vaccinated against plague before a next vaccination campaign starts basing on assessment of immunologic monitoring results obtained during a previous season; consequently, we can predict efficiency of antiplague protection and assess necessity (scope) of prevention activities and optimal time when next vaccination against this infection should be performed.

Basing on score estimates of immune reactivity obtained for volunteers vaccinated with LPV, we determined groups of people who reacted to plague microbe antigens predominantly as per cellular, humoral, or mixed type (Table 4).

Table 4

Number of people with reaction to LPV (Abs./\%)

\begin{tabular}{|c|c|c|c|c|}
\hline $\begin{array}{c}\text { Score } \\
\text { estimate }\end{array}$ & $\begin{array}{c}\text { Immune } \\
\text { response } \\
\text { type }\end{array}$ & $\begin{array}{c}\text { Group 1 } \\
(n=20)\end{array}$ & $\begin{array}{c}\text { Group 2 } \\
(n=76)\end{array}$ & $\begin{array}{c}\text { Group 3 } \\
(n=100)\end{array}$ \\
\hline 1 & $\begin{array}{c}\text { No re- } \\
\text { sponse }\end{array}$ & $6(30 \%)$ & $7(9 \%)$ & $6(6 \%)$ \\
\hline 2 & Humoral & $6(30 \%)$ & $14(18 \%)$ & $10(10 \%)$ \\
\hline 3 & Mixed & $5(25 \%)$ & $30(40 \%)$ & $51(51 \%)$ \\
\hline 4 & Cellular & $3(15 \%)$ & $25(33 \%)$ & $33(33 \%)$ \\
\hline
\end{tabular}

According to the obtained data, a share of people with predominantly cellular or mixed response was authentically higher in Group 3, and, bearing in mind that it is cellular immunity that plays a leading role in protection from plague, we can conclude that specific prevention was more efficient in this group $[17,20]$.

Population immunity characteristic is a basic risks related to anticipatory effect produced by mass anti-plague vaccination. But we should remember that endogenous risks related to population immunity formation are to a great extent determined by peculiar immune reactivity of each vaccinated person [6].

Our assessment allowed revealing people with both normal and changed (increased or decreased) immunologic reactivity to LPV among volunteers who got vaccinated with the preparation. Parameters obtained for volun- 
teers with changed reactivity were beyond the suggested score range. In case a respondent had normal immune reactivity to plague microbe, it was optimal and economically justified to apply LPV according to a standard procedure as per epidemiologic indications, namely 1 month prior to future activities in a natural plague focus given a predicted growth in epizootic activity. In case a person has lower immune reactivity, it is necessary to work out certain activities aimed at raising immunologic competence and creating individual vaccination schedules in such a way so that not less than 1 month and not longer than 6 months passed after vaccination by the moment epizootic activity in natural plague focus reached its peak. "Vaccine protection» program was implemented for getting population protected from certain vaccine-manageable infections as a part of the National Prevention Vaccination Calendar and it provided an opportunity to raise population immunity efficiency due to various schemes of specific response immune modulation [21]. At the same time, in case a person has elevated immune reactivity, it is permissible to pursue individual approach to revaccination taking into account existing risks and actual probability that epidemiologic situation might deteriorate.

Therefore, basing on immunologic monitoring results, we proved it was safe to apply LPV and it was possible to predict results of vaccination as per epidemic indications taking into account detected groups of people with normal, high, and low immune reactivity to plague microbe antigens. The latter was done in order to determine people who needed an individual approach to anti-plague vaccination; therefore, we managed to minimize risks related to excessive of insufficient scopes of activities aimed at specific plague prevention in natural foci.

Funding. The research was not granted any financial support.

Conflict of interests. The authors declare there is no any conflict of interests.

Acknowledgement. We express our gratitude to supervisors and personnel of Rospotrebnadzor Regional office in Kalmyk Republic, Center for Hygiene and Epidemiology in Kalmykia, Rospotrebnadzor's Elista Anti-Plague Station and Astrakhan Anti-Plague Station for their assistance rendered in organizing clinical materials collection.

\section{References}

1. Matrosov A.N., Sintsov V.K., Mandzhieva V.S., Golosovskii S.M., Kim T.S., Leshchuk V.A., Kuznetsov A.A., Porshakov A.M. [et al.]. Factors that predetermined activation of plague epizooties in the pre-Caspian sandy natural focus in 2014. Problemy osobo opasnykh infektsii, 2015, no. 4, pp. 30-35 (in Russian).

2. Popov N.V., Kuznetsov A.A., Matrosov A.N., Korzun V.M., Verzhutskii D.B., Vershinin S.A., Kosilko S.A., Innokent'eva T.M. [et al.]. Epizootic activity of natural plague foci of the Russian Federation in 2008-2017 and forecast for 2018. Problemy osobo opasnykh infektsii, 2018, no. 1, pp. 50-55 (in Russian).

3. Matrosov A.N., Lopatin A.A., Popov N.V., Porshakov A.M., Kuznetsov A.A., Golosovskii S.M., Sintsov V.K., Mandzhieva V.S., Sandzhiev D.N. Non-specific prophylaxis of plague in the natural sandy focus of the Caspian sea region. Zdorov'e naseleniya i sreda obitaniya, 2015, vol. 262, no. 1, pp. 30-32 (in Russian).

4. Bugorkova S.A., Shchukovskaya T.N., Mikshis N.I., Shcherbakova S.A., Kudryavtseva O.M., Kuklev E.V., Dubrovina V.I., Noskov A.K. [et al.]. Scientific and methodological support of activities on carrying out immunological monitoring of vaccinated against plague persons residing in the territories of natural foci of the infection. Problemy osobo opasnykh infektsii, 2018, no. 2, pp. 6-13 (in Russian).

5. Popova A.Yu., Kutyrev V.V., Balakhonov S.V., Ezhlova E.B., Demina Yu.V., Pakskina N.D., Shchuchinov L.V., Popov N.V. [et al.]. Coordination of measures of plague control institutions, aimed at rehabilitation and sanitation of Gorno-Altai high-mountain natural plague focus in 2016. Problemy osobo opasnykh infektsii, 2016, no. 4, pp. 5-10 (in Russian).

6. Fel'dblyum I.V. Risk-management in the field of vaccine prevention as one of the directions of ensuring epidemiological and biological safety. Epidemiologiya i vaktsinoprofilaktika, 2018, vol. 17, no. 5, pp. 25-30 (in Russian). 
7. Movsesyants A.A. Bezopasnost' immunizatsii: riski, svyazannye s vaktsinoi [Immunization safety: risks related to vaccination]. Biopreparaty. Profilaktika, diagnostika, lechenie, 2009, vol. 33-34, no. 1-2, pp. 33-36 (in Russian).

8. Bridges J.F. Lean systems approaches to health technology assessment: a patient-focused alternative to cost-effectiveness analysis. PharmacoEconomics, 2006, vol. 24, no. 2, pp. 101-109. DOI: 10.2165/00019053-200624002-00011

9. Immunologicheskie metody [Immunologic procedures]. In: G. Frimel' ed. Moscow, Meditsina Publ., 1987, 472 p. (in Russian).

10. Glants S. Mediko-biologicheskaya statistika [Medical and biological statistics]. Moscow, Praktika Publ., 1999, 334 p. (in Russian).

11. Rebrova O.Yu. Statisticheskii analiz meditsinskikh dannykh. Primenenie paketa prikladnykh programm STATISTICA [Statistical analysis of medical data. Application of STATISTICA software]. Moscow, MediaSfera Publ., 2002, 70 p. (in Russian).

12. Korytov K.M., Voitkova V.V., Dubrovina V.I., Pyatidesyatnikova A.B., Noskov A.K., Glushkov E.A., Akimova I.S., Ondar N.V. [et al.]. Efficiency of human plague vaccination in Tuvinian natural plague focus. Acta Biomedica Scientifica, 2019, vol. 4, no. 5, pp. 31-37 (in Russian).

13. Bugorkova S.A., Shchukovskaya T.N., Mikshis N.I., Klyueva S.N., Kudryavtseva O.M., Kravtsov A.L., Goncharova A.Yu., Kozhevnikov V.A. [et al.]. Comprehensive immunological study of persons vaccinated with live plague vaccine living on the territory of the pre-Caspian sand foci of the plague in the republic of Kalmykia. Epidemiologiya i vaktsinoprofilaktika, 2018, vol. 17, no. 3, pp. 38-50 (in Russian).

14. Sodhi A., Tarang S., Kesherwani V. Concanavalin A induced expression of Toll-like receptors in murine peritoneal macrophages in vitro. Int Immunopharmacol, 2007, vol. 7, no. 4, pp. 454-463. DOI: 10.1016/j.intimp.2006.11.014

15. Korytov K.M., Voitkova V.V., Dubrovina V.I., Noskov A.K., Mishchenko A.I., Mikhailov E.P., Balakhonov S.V., Shchuchinov L.V. Immunological efficiency of human plague vaccination in the Gorno-Altai high-mountain natural plague focus. Epidemiologiya $i$ vaktsinoprofilaktika, 2018, vol. 17, no. 6, pp. 87-97 (in Russian).

16. Byvalov A.A., Dubrovin M.Yu., Elagin G.D., Pechenkin D.V., Bondarev V.P. Relationship between the level of serum rearrangement of vaccinated animals and the stress of immunity to experimental plague. Klinicheskaya laboratornaya diagnostika, 2007, no. 7, pp. 48-51 (in Russian).

17. Philipovskiy A.V., Smiley S.T. Vaccination with live Yersinia pestis primes CD4 and CD8 T cells that synergistically protect against lethal pulmonary $Y$. pestis infection. Infection and Immunity, 2007, vol. 75, no. 2, pp. 878-885. DOI: 10.1128/IAI.01529-06

18. Ketlinskii S.A. Rol' T-khelperov tipov 1 i 2 v regulyatsii kletochnogo i gumoral'nogo immuniteta [Role played by type I and II T-helpers in cellular and humoral immunity regulation]. Immunologiya, 2002, no. 2, pp. 77-79 (in Russian).

19. Parent M.A., Berggren K.N., Kummer L.W., Wilhelm L.B., Szaba F.M., Mullarky I.K., Smiley S.T. Cell-mediated protection against pulmonary. Yersinia pestis infection. Infect. Immun., 2005, vol. 73, no. 11, pp. 7304-7310. DOI: 10.1128/IAI.73.11.7304-7310.2005

20. Do Y., Didierlaurent A.M., Ryu S., Koh H., Park C.G., Park S., Perlin D.S., Powell B.S., Steinman R.M. Induction of pulmonary mucosal immune responses with a protein vaccine targeted to the DEC-205/CD205 receptor. Vaccine, 2012, vol. 30, no. 45, pp. 6359-6367. DOI: 10.1016/j.vaccine.2012.08.051

21. L'vova I.I., Fel'dblyum I.V., Koryukina I.P., Yakovlev I.B. Programma «Vaktsinoprotektsiya» kak odin iz sposobov povysheniya effektivnosti spetsificheskoi profilaktiki difterii i kori u detei [«Vaccineprotection» program as a way to increase efficiency of specific diphtheria and measles prevention in children]. Byulleten' Vostochno-Sibirskogo nauchnogo tsentra SO RAMN, 2002, no. 4, pp. 65-68 (in Russian).

Bugorkova S.A., Klyueva S.N., Kudryavtseva O.M., Toporkov V.P., Shchukovskaya T.N., Kravtsov A.L., Mikshis N.I., Tarasov M.A., Shcherbakova S.A., Kutyrev V.V. Immunologic monitoring over people vaccinated against plague in Caspian sand natural focus in order to assess and manage health risks. Health Risk Analysis, 2020, no. 4, pp. 121-129. DOI: 10.21668/health.risk/2020.4.14.eng

Received: 11.08.2020

Accepted: 11.11.2020

Published: 30.12.2020 